\title{
Miscellanea
}

MICHAE SOLIWODA

Instytut Ekonomiki Rolnictwa

i Gospodarki Żywnościowej - PIB

Warszawa

\section{DYLEMATY WOKÓŁ WYMIARU FINANSOWEGO ZRÓWNOWAŻENIA GOSPODARSTW ROLNICZYCH}

\begin{abstract}
Abstrakt
Zrównoważenie, jako swoista „metakategoria”, rozpatrywana w ujęciu inter-, czy nawet transdycyplinarnym, odnosi się również do zjawisk o charakterze monetarnym. Dotychczas ujęcie finansowe zrównoważenia gospodarstw rolniczych nie zostało wyeksponowane.

Celem opracowania jest uwypuklenie wybranych kwestii teoretyczno-metodologicznych, zwiąanych z wymiarem finansowym zrównoważenia gospodarstw rolniczych. Przyjęto nastepujace cele szczegółowe: (1) powiazanie dorobku teoretycznego i aparatu metodologicznego dotyczacego wzrostu zrównoważonego ( $w$ ujęciu finansowym) gospodarstw rolniczych z koncepcjami zrównoważenia, (2) zidentyfikowanie asocjacji między wzrostem zrównoważonym a wybranymi problemami zarzadzania gospodarstwami rolniczymi i polityki agrarnej. Opieranie się na kategorii dochodu rolniczego (w tym np. dochód z rodzinnego gospodarstwa rolniczego, net farm income), z pomijaniem sytuacji finansowej gospodarstwa, stanowi pewne uproszczenie spłycające ramy analityczne zrównoważenia. Pojęcia „wzrostu zrównoważonego”, „stopy wzrostu zrównoważonego”, „zrównoważonej intensyfikacji” moga rozszerzyć dotychczasowe ramy analizy zrównoważenia gospodarstw rolniczych, a także być przesłanką do konstruowania/udoskonalania instrumentów wspomagajacych zarzadzanie gospodarstwem czy monitoring iocene skutków polityki rolnej.
\end{abstract}

Słowa kluczowe: zrównoważenie, wzrost zrównoważony, finanse rolnictwa, metodologia finansów, gospodarstwo rolnicze 


\section{Wprowadzenie}

„Płaszczyznę” równoległą do problematyki badawczej związanej ze zrównoważeniem gospodarstw rolniczych, a także rozwoju zrównoważonego rolnictwa, tworzy „matryca” terminologiczna wraz z instrumentarium metodycznym dotyczącym wzrostu i rozwoju podmiotów sektora rolnego ${ }^{1}$. Ujęcie finansowe zrównoważenia gospodarstw rolniczych nie jest eksponowane, co skłania do podjęcia rozważań teoretycznych i metodologicznych w tym obszarze.

Celem opracowania jest uwypuklenie wybranych kwestii teoretyczno-metodologicznych, związanych z wymiarem finansowym zrównoważenia gospodarstw rolniczych. Przyjęto następujące cele szczegółowe: (1) powiązanie dorobku teoretycznego i aparatu metodologicznego dotyczącego wzrostu zrównoważonego (w ujęciu finansowym) gospodarstw rolniczych z koncepcjami zrównoważenia; (2) zidentyfikowanie asocjacji między wzrostem zrównoważonym a wybranymi problemami zarządzania gospodarstwami rolniczymi i polityki agrarnej. Artykuł stanowi asumpt do pogłębionych badań empirycznych nad wzrostem zrównoważonym gospodarstw rolniczych, w szczególności identyfikacją zależności między wspomnianą kategorią a bezpieczeństwem i stabilnością finansową. Całość opracowania kończą wnioski i rekomendacje.

\section{Płaszczyzna finansowa zrównoważenia podmiotów gospodarczych}

Zrównoważenie - jako swoista ,metakategoria”, rozpatrywana w ujęciu inter-, czy nawet transdycyplinarnym ${ }^{2}$ - odnosi się również do zjawisk o charakterze monetarnym. Należy odwołać się do definicji ,zrównoważenia”, związanych na ogół z działalnością gospodarczą (por. business sustainability). Problemy natury terminologicznej mogą wynikać z (Financial Times, 2014):

- konieczności uwypuklenia procesów zarządzania kategoriami ryzyka o charakterze finansowym, społecznym i środowiskowym (profits - people-planet, 3P, tzn. ,zogniskowanie” działalności na zyski - ludzie - planetę) - jest to jednak podejście krytykowane ze względu na brak uwzględnienia czynnika czasu i bazowanie na tradycyjnych kategoriach wypracowanych przez praktykę raportowania biznesowego, w tym rachunkowości (Scerri A., James P., 2010);

- „elastyczności” podmiotu gospodarczego w ujęciu dynamicznym - podmioty gospodarcze mają zdolność do przetrwania szoków i kryzysów, ponieważ są powiązane ze ,zdrowymi” systemami ekonomicznymi (w tym finansowy$\mathrm{mi}$ ), społecznymi i środowiskowymi.

\footnotetext{
${ }^{1}$ Ujęcie mikroekonomiczne, dotyczące głównie przedsiębiorstw sektora prywatnego, charakteryzuje się wieloma niejasnościami definicyjnymi i lukami metodycznymi (por. Zhou H., Wit G. de, 2009). Kontrastuje to mnogością opracowanych koncepcji teoretycznych na poziomie makro (identyfikacja przyczyn wzrostu gospodarczego, formułowanie teorii opisujących tę kategorię), poczynając od klasycznych, m.in. A. Smitha, D. Ricardo, Th. Malthusa, J.S. Milla, a także marksistowskich, heterodoksyjnych, np. J.S. Schumpetera.

${ }^{2}$ R.W. Kates i in. (2000, s. 1) twierdzą wręcz, że można wyodrębnić naukę o zrównoważeniu (sustainability science), skupionej na „dynamicznych interakcjach między środowiskiem przyrodniczym a społeczeństwem”. Ze stwierdzeniem tym można polemizować.
} 
Jak wynika z powyższego, istotne jest ukierunkowanie ,prospektywne”, związane z koniecznością zaspokojenia potrzeb przyszłych pokoleń. Zrównoważenie podmiotów gospodarczych wiąże się ze spełnianiem jednocześnie następujących kryteriów (Financial Times, 2014): (i) efektywności ekonomicznej (obszary innowacji, dobrobytu, wydajności); (ii) sprawiedliwości społecznej (wrażliwości na ubóstwo, wspólnoty lokalne, dobrobyt, respektowanie praw człowieka) i (iii) troski za środowisko (m. in. zmiany klimatu, użytkowanie gruntów, różnorodność biologiczna).

W swoim opus magnum J.S. Zegar (2012, s. 88) stwierdza, że w odniesieniu do rolnictwa zrównoważenie ,można rozpatrywać na różnych poziomach, poczynając od konkretnego pola, uprawy czy innej działalności rolniczej, przez gospodarstwo rolne, poziom lokalny, regionalny i krajowy, a kończąc na kontynentalnym i globalnym". Największy postęp metodyczny zauważyć należy w odniesieniu do kwantyfikacji zrównoważenia gospodarstw rolniczych. Istnieje już wszak rozbudowany zestaw wskaźników zrównoważenia, dotyczący kryteriów sozologicznych (w odniesieniu do gospodarstwa rolnego ${ }^{3}$ ), ekonomicznych (głównie bazujących na dochodzie z rodzinnego gospodarstwa rolniczego) i społecznych.

Swoistym łącznikiem między koncepcjami zrównoważenia sensu largo a teorią finansów jest coraz bardziej zauważana i eksplorowana problematyka nierównowagi finansowej, powiązanej ze wzrostem i rozwojem finansowym - na różnych poziomach. W oryginalnej koncepcji klasyfikacji obszarów finansów według kryterium ,poziom analizy instytucjonalnej”, autorstwa J.K. Solarza (2012, s. 7-8), na wierzchołku swoistej piramidy znajdują się „metafinanse”. Ta część teorii finansów dotyczy architektury w systemie finansowym. Przedmiotem analizy czyni zjawiska nierównowagi. „Makrofinanse”, skoncentrowane wokół analizy dóbr publicznych, rozpatrują ,trwałość wzrostu gospodarczego”, a także „zrównoważone rynki finansowe”. J.K. Solarz uważa, że analiza instytucjonalna może sięgać nawet poziomu psychiki człowieka, co może umożliwiać rozpoznanie np. motywów oszczędnościowych członków gospodarstwa domowego. Postulat J.K. Solarza wprowadzenia nowego obszaru dociekań finansów, tzn. „,nanofinansów”, wynika z krytycznego spojrzenia na dominujące dotychczas w naukach ekonomicznych metody badawcze. Jak słusznie stwierdza J.K. Solarz (2012, s. 10), ,zagwarantowanie gospodarstwom domowym dostępu do profesjonalnego zarządzania ryzykiem finansowym" będzie warunkiem sine qua non „zapewnienia trwałego wzrostu gospodarczego". Również A. Wojtyna (2011), poszukując odpowiedzi na pytanie, dlaczego ekonomia ,głównego nurtu” nie była w stanie przewidzieć globalnego kryzysu finansowego (2007+), stwierdza, że rezultatem tego „niepowodzenia” może stać się stopniowe włączanie pozostałych dyscyplin nauk ekonomicznych. Podej-

\footnotetext{
${ }^{3}$ Liczne wskaźniki dotyczące zrównoważenia środowiskowego zostały zaprezentowane w pracach: Baum R., 2008; Wrzaszcz W., 2012, Wrzaszcz W., 2013, Zrównoważenie..., 2013.
} 
ściem badawczym umożliwiającym dokładną analizę zrównoważenia gospodarstw w wymiarze finansowym może stać się komparatystyka, której rozwój wynika z megatrendów w gospodarce światowej (Flejterski S., 2015).

Reasumując, zrównoważenie, jako kategoria stanowiąca pochodną koncepcji zrównoważonego rozwoju, obejmuje aspekty ekonomiczne, ekologiczne i środowiskowe. Wraz z wyodrębnieniem finansów jako autonomicznej dyscypliny naukowej oraz pogłębianiu powiązań gospodarstw rolniczych z infrastrukturą finansową, wzrastać będzie znaczenie przypisywane wymiarowi finansowemu zrównoważenia, który jest obecnie integrowany z kryteriami ekonomicznymi (tzn. pewne miary i wskaźniki finansowe tworzą niejako podzbiór ilustrujący zrównoważenie ekonomiczne). Sprzyjać temu może upowszechnienie informacyjnych systemów wspomagania decyzji w polskim rolnictwie, a przede wszystkim popularyzacji metod uproszczonej nawet ewidencji księgowej, a w ślad za nią sprawozdawczości finansowej.

\section{Paradygmat wzrostu zrównoważonego w odniesieniu do gospodarstw rolniczych}

Wzrost przedsiębiorstwa stanowi obecnie jeden z najbardziej interesujących obszarów badań ekonomicznych, ze swej natury wymagający podejścia interdyscyplinarnego. Wynika to, jak słusznie zauważa M.T. Carrizosa (2006), z silnego powiązania wzrostu ze zdolnością podmiotu gospodarczego do przeżycia (firm survival). Ogólna tendencja do wzrostu przedsiębiorstw w danym sektorze może wpływać na przyspieszanie tempa wzrostu gospodarczego. Wzrost podmiotów gospodarczych staje się ponadto motywem skłaniającym zarządzających do wprowadzania innowacji w przedsiębiorstwach.

Powszechna historia gospodarcza wskazuje, że z punktu widzenia różnic interesów państwa, właścicieli ziemskich, siły roboczej, określenie „,subtoptymalnej" (przynajmniej pod względem dobrobytu społecznego) wielkości gospodarstwa było kwestię niezwykle problematyczną ${ }^{4}$. Również pierwotnie stosowane kryterium (wielkość gospodarstwa rozumiana jako areał upraw), jako swoista cezura do odróżnienia gospodarstw małych do rozwojowych, ma charakter bardzo orientacyjny (Zegar J.S., 2012). Podobnie, różne, ale wykorzystywane pojedynczo kryteria ekonomiczne, będące nadwyżkami ekonomicznymi (np. wartość dodana), nie odzwierciedlają zawiłości kwantyfikacji wzrostu gospodarstwa. W zależności od typu reprezentowanego nurtu ekonomicznego, badacze wykazywali zróżnicowane podejście do wzrostu gospodarstwa: w podejściu klasycznym i neoklasycznym podkreślana jest duża rola gospodarstw wielkopowierzchniowych (farm). Z kolei, ekonomiści nurtu marksistowskiego uznali słuszność powiększania areału dla gospodarstw reprezentujących charakter uspołeczniony (por. Perelman M., 1975; Saito K., 2014).

\footnotetext{
${ }^{4}$ Wynika to także $\mathrm{z}$ rozważań nad tzw. kwestią agrarną $\mathrm{w}$ ujęciu ewolucyjnym, podjętych przez A. Czyżewskiego i A. Matuszczak (2011).
} 
Można zauważyć, że już ekonomiści klasyczni podkreślali, że na wzrost gospodarki należy nałożyć pewne warunki ograniczające. Pewnym łącznikiem spajającym idee zrównoważania rolnictwa (również na poziomie mikro) jest koncepcja steady state economics J.S. Milla (odnosząca się początkowo do gospodarki państwa). Owa koncepcja stała się punktem wyjścia dla modelu wzrostu Solowa-Swana, motywowała także przedstawicieli ekonomii ekologicznej (ecological economics) do formułowania ograniczeń natury przyrodniczej wzrostu gospodarczego i opisu wymagań, jakie powinny być stawiane „zrównoważonej gospodarce" (sustainable growth) (Anderson M., 2012).

Tematyka wzrostu gospodarstw rolniczych w ujęciu finansowym budziła duże zainteresowanie wśród badaczy, zwłaszcza z kręgu krajów anglosaskich. Ma to swoje uzasadnienie w tym, że „filar normatywny” współczesnych dyscyplin nauk ekonomicznych dotyczy m. in. identyfikacji „czynników sukcesu” podmiotów gospodarczych. Jak słusznie zauważają C.L. Escalante i in. (2009), istotną rolę, pod kątem widzenia powiązania wielkości produkcji (w rezultacie, przychodów ze sprzedaży) z decyzjami finansowymi rolników, odgrywa paradygmat wzrostu zrównoważonego (sustainable growth paradigm, SGP), sformułowany już pod koniec lat 70. XX w. przez R.C. Higginsa ${ }^{5}$. Teoria finansów przedsiębiorstw (corporate finance) wypracowała aparat definicyjny i narzędzia do kwantyfikacji tego rodzaju zrównoważenia (w tym modele finansowe). Kluczowe jest pojęcie „stopy wzrostu zrównoważonego" (sustainable growth rate, SGR), oznaczające maksymalną stopę wzrostu, na którą podmiot gospodarczy może pozwolić sobie bez podwyższania dźwigni finansowej ${ }^{6}$.

Modele mające zastosowanie do przedsiębiorstw (głównie spółek kapitałowych) oparte są na kilku założeniach: (1) zachowanie docelowej struktury kapitałowej bez podwyższania poziomu kapitału własnego; (2) utrzymanie docelowej stopy wypłat dywidendy; (3) wzrost sprzedaży - tak szybko, jak tylko pozwolą na to warunki rynkowe. Ponieważ głównym źródłem dla nowego kapitału własnego są przede wszystkim zyski zatrzymane, wartość przychodów ze sprze-

\footnotetext{
${ }^{5}$ Koncepcja Higginsa powstała w niestabilnym okresie rozwoju gospodarki USA (lata 70. XX w. - kryzys naftowy i jego konsekwencje, $\mathrm{m}$. in. stagflacja) zakłada stałe tempo wzrostu przychodów sprzedaży przy ograniczeniu polityki finansowej (docelowe: relacja dług/ kapitał własny, wskaźnik wypłat dywidendy, marża zysku, aktywa ogółem/sprzedaż netto). Ramy koncepcyjne stworzone przez Higginsa dają podstawę do kalkulacji SGR.

${ }^{6}$ Stopa wzrostu zrównoważonego, pierwotnie stosowana w odniesieniu do spółek giełdowych jako dorobek finansów korporacyjnych, wynika z przyjęcia założenia o ograniczonym finansowaniu: (1) wzrost kapitału własnego jako konsekwencja pozostawienia części zysków, (2) relacja zadłużenie/kapitał własny nie ulegnie zmianie. Ujmując to równaniem (Bodie Z., Merton R.C., 2003, s. 139):
}

stopa wzrostu zrównoważonego $=$ stopa zysku zatrzymanego $\cdot$ ROE.

Jak wynika z powyższego równania, zysk (a w przypadku rodzinnego gospodarstwa rolniczego dochód) powinien być zatrzymany. W przypadku podmiotów sektora rolnego (w większości gospodarstwa osób fizycznych, o relatywnie nieskomplikowanej strukturze kapitałowej) zarządzający mają możliwość przyspieszenia wzrostu powyżej ROE, pod warunkiem powiększenia wskaźnika zadłużenia. 
daży i wartość aktywów nie mogą przyrastać szybciej niż zyski zatrzymane + dodatkowy dług. W rzeczywistości, stopa SGR powiązana jest ze wskaźnikiem ROE, który jest przydatny do określania stopy zrównoważenia.

$\mathrm{Z}$ mikroekonomicznego punktu widzenia, procesy wzrostu (utożsamiane z powiększaniem poziomu kapitałów własnych gospodarstw) są pożądane, umożliwiają bowiem gospodarstwom rolniczym korzystanie $\mathrm{z}$ pozytywnych efektów skali. Możliwości wynikające z tych zalet zostały dosyć dobrze rozpoznane w ekonomice rolnictwa. J.C. Hadrich i F. Olson (2011) zauważają, że znaczny problem (biorąc pod uwagę zachodzące i pożądane przez decydentów politycznych przemiany strukturalne w rolnictwie) stanowi pojęcie ,wielkości gospodarstwa rolniczego" (farm size). Choć w XX w. amerykańscy ekonomiści rolnictwa (np. E.O. Heady) wiązali tę kategorię z areałem gospodarstwa i wartością produkcji rolniczej, z czasem jednym z wyróżników wielkości gospodarstwa stały się również przychody ze sprzedaży brutto (gross sales). Ma to swoje odzwierciedlenie m. in. w definicji zaproponowanej przez K. Olsona i L. Vu (2009). Z perspektywy zarządzających gospodarstwami jest to równie istotne jak rozpoznanie, jakie ma być tempo wzrostu, aby skorzystać z zakumulowanego dochodu (retained earnings) i dodatkowo obcych źródeł finansowania (Moss Ch., 2013). Zgodnie z wynikami badań A. Schimke i Th. Brenner (2011), dotyczących co prawda przedsiębiorstw niemieckich, średnie wysokie stopy wzrostu i ścieżki rozwoju przedsiębiorstw nie są tożsame. Eksploracja przyczyn rozwoju przedsiębiorstw jest na tyle złożonym procesem, że rozpoznanie czynników wyjaśniających wzrost okazuje się niewystarczające.

Fundamentalne znaczenie pod kątem uporządkowania zależności między efektywnością finansową, strategiami operacyjnymi i finansowymi gospodarstwa rolniczego miała praca C.L. Escalante i in. z 2009 (por. Budżetowe podstawy..., 2014). Istotnym jej wkładem jest pomiar stóp wzrostu zrównoważonego farm zbożowych i wyspecjalizowanych $\mathrm{w}$ produkcji zwierzęcej $\mathrm{w}$ stanie Illinois. Tabela 1 zestawia kluczowe zależności, które posłużyły zespołowi C.L. Escalante (2009) do realizacji studium empirycznego.

W tabeli 2 zestawiono cele, założenia metodyczne oraz kluczowe wyniki badań strategii wzrostu gospodarstw domowych - w odniesieniu do celów monetarnych tych podmiotów. Choć zaprezentowane studia empiryczne dotyczyły podmiotów sektora rolnego w USA, to niektóre konkluzje można odnieść też do rodzinnych gospodarstw rolniczych w UE. Do daleko idących wniosków doszedł zespół A.K. Mishry (2012): typ produkcyjny, kontrakcja i specjalizacja okazały się istotnymi determinantami struktury kapitałowej (dokładnie: relacji aktywa/ kapitał własny). 


\section{Stopa wzrostu zrównoważonego - ujęcie dla gospodarstw rolniczych}

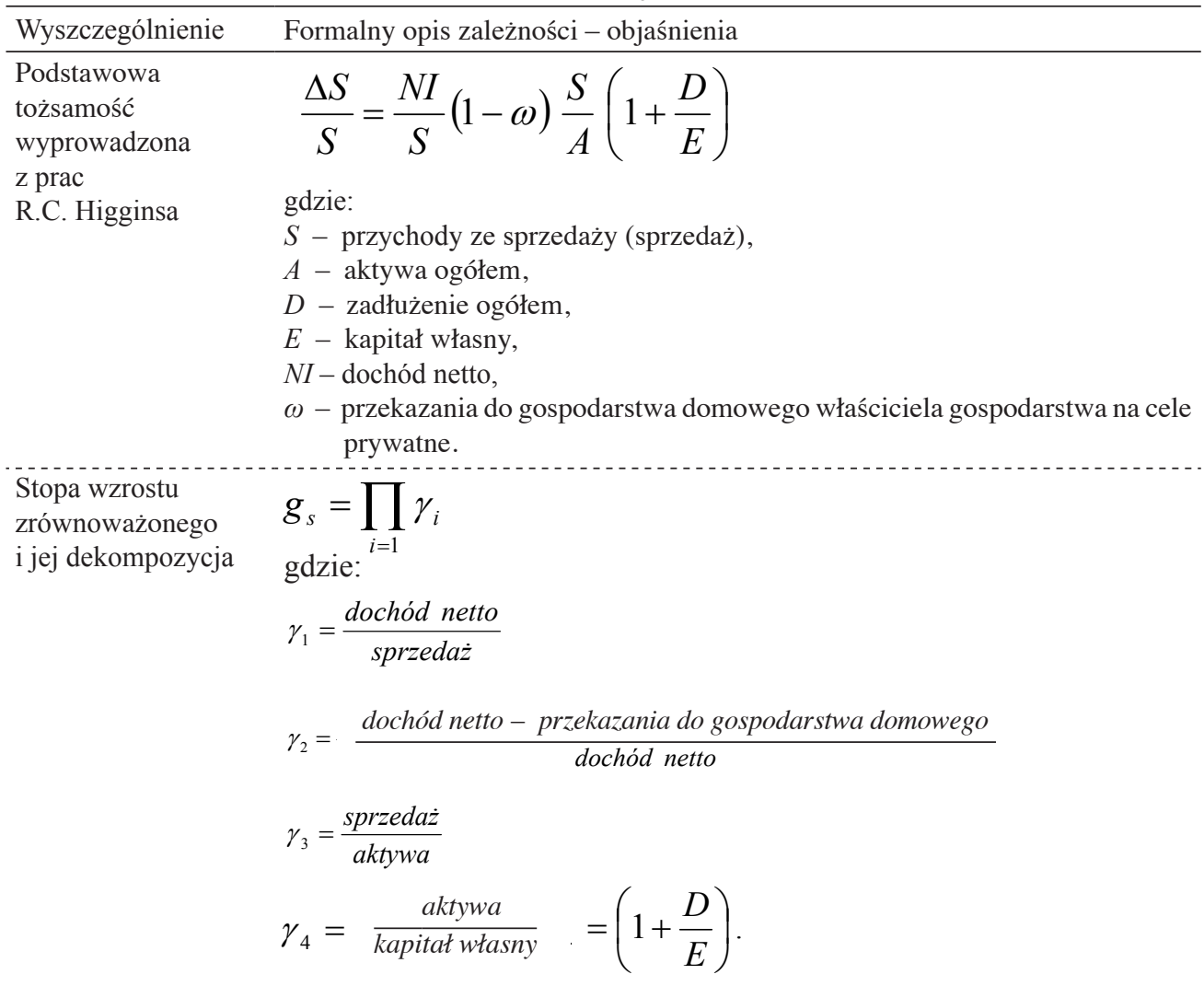

Stopa

zrównoważonego

wzrostu (SGC)

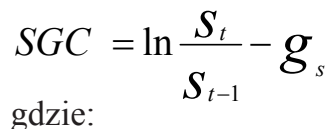

$S_{t} S_{t-1}$ - przychody ze sprzedaży odpowiednio: w momencie t, t-1

$\mathrm{g}_{\mathrm{s}} \quad$ - stopa wzrostu sprzedaży

$g_{s}=R O E \frac{\text { kapitał wtasny na koniec okresu }}{\text { kapitat wtasny na poczatku okresu }}$

$g_{s}=\frac{b \cdot R O E}{1-(b \cdot R O E)}$

Objaśnienie: szczegółowe tłumaczenia przyjęto za opracowaniem „Budżetowe podstawy...” (2014), w pozycji tej znajdują się odniesienia bibliograficzne do przywoływanych modeli (m.in. Escalante C.L. i in., 2009).

Źródło: Opracowanie własne (z uwzględnieniem rozważań w „Budżetowe podstawy...”, 2014). 
Jak zauważa C.L. Escalante i in. (2009), planowany wzrost w rolnictwie opiera się na długookresowych przewidywaniach. Zmienność cen artykułów rolno-spożywczych, a także wysokości plonów wpływają na bieżący rozwój. Niekorzystną jest sytuacja, jeśli planowana stopa wzrostu przekracza zrównoważoną stopę wzrostu; niezbędne jest wówczas sięgnięcie po obce źródła finansowania (kredyty i pożyczki). W odwrotnej sytuacji (planowana stopa wzrostu < zrównoważona stopa wzrostu) zasoby majątkowe nie są w pełni wykorzystywane, natomiast środki pieniężne są akumulowane na ogół w sposób nieproduktywny. Ekonomiści amerykańscy twierdzą, że przychody gospodarstwa wyższe od przewidywanych są pewnego rodzaju źródłem ryzyka, prowadzą bowiem do zwiększenia przepływów pieniężnych i wzrostu zapotrzebowania na kapitał obrotowy.

Obok ,tradycyjnej” SGR, zaproponowanej przez R.C. Higginsa (1977), powstała relatywnie nowa koncepcja Optimal Growth (OG), autorstwa M. Handschuha $\mathrm{i}$ in. (2014). Oceniany jest tu wzrost z perspektywy kreowania zdolności stopy zwrotu dla akcjonariuszy (total shareholder return, TSR) i perspektywy zyskowności niezależnej od przyjętej strategii, modelu biznesowego czy ram polityki finansowej podmiotu. Koncepcja OG bazuje na ocenach w perspektywie długoterminowej i tworzy podstawy do wyznaczania celu wzrostu długoterminowego.

Reasumując, koncepcja wzrostu zrównoważonego wiąże bardzo istotne kategorie: wzrostu oraz zrównoważenia. Z punktu widzenia analiz w skali mikro coraz większą rolę mogą odegrać koncepcje integrujące powiązanie między stopą wzrostu kapitałów własnych, zadłużeniem (bądź też dźwignią finansową) a zwiększaniem się przychodów sprzedaży produktów rolnych. Ma to duże znaczenie $\mathrm{w}$ rolnictwie, którego immanentną cechą jest wysoki poziom ryzyka cenowego, a w rezultacie zmienność dochodów, co stanowi przesłankę do kierowania do podmiotów sektora rolnego instrumentów wsparcia, np. dopłat bezpośrednich (por. Kowalski A., 2014). Pewne nadzieje można też wiązać z uwzględnieniem w ujęciu modelowym kategorii sub/optimum dla interesariuszy i perspektywy horyzontu czasowego, czego przekładem może być relatywnie nowa koncepcja OG. 


\section{Wzrost finansowy gospodarstw rolniczych - przegląd badań empirycznych z USA}

\begin{tabular}{lll}
\hline \multirow{2}{*}{$\begin{array}{l}\text { Wyszcze- } \\
\text { gólnienie }\end{array}$} & \multicolumn{2}{c}{ Autorzy } \\
\cline { 2 - 3 } & C.L. Escalante i P.J. Barry (2002) & A.K. Mishra i in. (2012)
\end{tabular}

Cel badań Próba identyfikacji głównych strategii wzrostu wykorzystywanych przez farmy zbożowe w stanie Illinois

Zbadanie wpływu cech socjodemograficznych, stopnia specjalizacji, tytuł prawa do własności, lokalizacja gospodarstwa na trzy dźwignie zyskowności (ROE), tzn. marże wyniku finansowego netto, wskaźnik rotacji aktywów oraz stosunek aktywów do kapitału własnego.

Założenia • Panel podmiotów obejmuje okres 1996-1999.

metodyczne - Realizowana (rzeczywista) stopa wzrostu kapitału własnego jest najbardziej odpowiednią miarą wzrostu gospodarstwa.

- Wartość kapitału, a także aktywów była określana metodą estimated cost value.

- Przyjęcie założenia, że zależność między przewidywaną stopą wzrostu kapitału własnego i jej kluczowymi determinantami finansowymi może być wyrażona jako średnia ważona różnicy między przewidywaną stopą ROA i kosztu długu (i), gdzie wagami są relacje aktywa/kapitał własny i dług/kapitał własny.

- W efekcie, stopa wzrostu kapitału własnego będzie zwiększać się wraz ze wzrostem ROA, zmniejszaniem ROI, stopy podatkowej i konsumpcji. Efekt ten będzie potęgowany wraz ze zwiększaniem poziomu dźwigni finansowej.

Kluczowe

wyniki

i konkluzje

łem) były wykorzystywane do przeciwdziałania
- Strategie (podzielone na dwie kategorie: ope- Wyodrębnione determinanty

racyjne oraz dotyczące zarządzania kapita- (key drivers) erozji kapitału własnego w trakcie niesprzyjających rolnikom faz cyklu koniunkturalnego. - Istotną rolę odgrywają ,działania zbiorowe", związane z poprawą przychodów, redukcją kosztów i strategiami zarządzania kapitałem. - Pozostałe źródła dochodu związane z zatrudnieniem i innymi alternatywami inwestowania poza gospodarstwem rolniczym stanowiły uzupełnienia dla niskich dochodów, osiąganych w analizowanym przedziale czasowym (1996-1999). Co więcej, uregulowanie wypłat na rzecz gospodarstwa rolniczego (głównie przez procesy dostosowujące styl życia, a także wzorce w zakresie wydatków rodzinnych) chroniły przed erozją kapitałów własnych w latach, w których gospodarstwa narażone były na ryzyko rynkowe (związane z niskimi ceny zbóż).
- marża wyniku finansowego netto: poziom wykształcenia kierującego, wielkość gospodarstwa, typ i specjali-

- Podejście badawcze bazowało na wykorzystaniu powiązanego układu/ systemu równań. Materiał badawczy obejmował dane z lata 1996-2009 na poziomie pojedynczych gospodarstw (w ramach USDA Agricultural Resource Management Survey, ARMS). Metodologia stosowana w tym badaniu wykorzystywała korektę heterogeniczności i opierała się na powtarzalnej procedurze przekrojowej estymowania modeli empirycznych z wykorzystaniem danych przekrojowych.

- Bardziej pogłębione wykorzystanie modelu Du Ponta.

zacja produkcyjna, ponadto wysokość płatności rządowych,

- wskaźnik rotacji aktywów: wiek kierującego gospodarstwem, kontraktacja, specjalizacja i otrzymywanie płatności rządowych,

- relacja aktywa/kapitał własny: wielkość gospodarstwa, typ produkcyjny, kontraktacja, specjalizacja. 
cd. Tabeli 2

- Kluczowe były strategie finansowania i zarządzania aktywami, m.in. minimalizowanie kosztów związanych z obsługą zadłużenia. Wiązało się z wykorzystaniem strategii refinansowania, a także planowej spłaty odsetek. Utrzymanie wysokiego poziomu produktywności aktywów przez pełne wykorzystanie zdolności produkcyjnych (excess farm capacity) było możliwe dzięki realizacji strategii zarządzania środkami trwałymi, obejmującymi ich likwidację czy ulepszenie, a w pewnych wypadkach również zakup (tj. inwestycje rzeczowe).

Objaśnienie: dane bibliograficzne przywołanych pozycji podano w „Spisie literatury”.

Źródło: Adaptacja rozważań: C.L. Escalante i P.J. Barry (2002), A.K. Mishra i in. (2012).

\section{Kategoria wzrostu zrównoważonego - implikacje dla zarządzania gospodarstwem rolniczym i polityki agrarnej}

Rodzinne gospodarstwo rolnicze - ze względu na swoją specyfikę ekonomiczno-społeczną wyróżnia się inną wiązką celów niż typowe przedsiębiorstwo w formie spółki kapitałowej (często z rozdziałem funkcji właścicielskiej od zarządzania podmiotem). Wynika to stąd, że gospodarstwo rolnicze, obok typowych funkcji ekonomicznych, charakterystycznych dla działalności biznesowej, musi realizować szereg funkcji społecznych, a także środowiskowych. Badania w Polsce w tym zakresie prowadzili m.in. W. Ziętara (1987) i E. Majewski (E. Majewski, W. Ziętara 1997). Jak wskazuje obecny dorobek nauk o zarządzaniu, dla organizacji gospodarczych możliwe jest uporządkowanie celów z uwzględnieniem ich hierarchizacji i pogrupowania.

Jednym $\mathrm{z}$ instrumentów zarządzania strategicznego, początkowo wykorzystywanym przez spółki giełdowe, była tzw. Zrównoważona Karta Wyników (Balanced Scorecard, BSC), której podwaliny teoretyczne zostały opracowane przez R.S Kaplana i D.P. Nortona $(1992,1996)$. Doświadczenia niektórych państw (np. Australia, Nowa Zelandia, Dania, Irlandia, USA) wskazują na możliwości zaadaptowania karty do specyfiki podmiotów sektora rolnego (Paustian M., Theuvsen L., 2014). Jak słusznie zauważają Ch. Noell i M. Lund (2003), trudności w upowszechnieniu BSC w rolnictwie wynikają z tego, że nie ma logicznej zależności między długo- i krótkoterminowym planowaniem, ponadto słabe jest też powiązanie między otoczeniem konkurencyjnym a wewnętrzną strukturą gospodarstw rolniczych. Zdaniem dwójki duńskich agroekonomistów, „zwiększenie udziału produkcji towarowej, uwarunkowania prawno-instytucjonalne o charakterze środowiskowym, potrzeby wynikające z bezpieczeństwa żywności, a także - ogólnie rzecz biorąc - wzrost poziomu ryzyka o charakterze gospodarczym (właściwie rynkowym, przypis M.S.), a także finansowego, skłania- 
ją do wykorzystania bardziej profesjonalnych technik zarządzania" (Noell Ch., Lund M., 2003, s. 2). Pewnym rozszerzeniem dla „tradycyjnej” Zrównoważonej Karty Wyników jest Sustainability Balanced Scorecard, zaproponowana przez F. Figge i in. (2002), a także przez Th. Biekera (2003). Zdaniem zespołu F. Figgego (2002), zintegrowanie wymiaru środowiskowego z aspektami społecznymi umożliwia holistyczne podejście do zarządzania organizacją gospodarczą.

$\mathrm{Z}$ punktu widzenia rozważanego tematu istotną rolę odgrywa perspektywa uczenia i wzrostu, która jest nadrzędną w stosunku do pozostałych perspektyw, co odnosi się również do podmiotów sektora rolnego (Lissitsa A., 2005). Jak zauważa H. Nörreklit (2000, s. 67), ,,właściwe podejście do stosowania BSC powinno opierać się na łączeniu działań z czterech perspektyw w łańcuchu przyczynowo skutkowym". W tabeli 3 przedstawiono fragmenty Zrównoważonej Karty Wyników, skonstruowanej z uwzględnieniem specyfiki gospodarstw mlecznych w Danii.

Tabela 3

Perspektywa finansowa w BSC dla gospodarstw mlecznych

\begin{tabular}{ll}
\hline \multicolumn{1}{c}{ Cele } & \multicolumn{1}{c}{ Mierniki } \\
\hline Zwiększyć dochód & Dochód \\
& Nośniki kosztów \\
Poprawić efektywność produkcji (production efficiency) & Nadwyżka bezpośrednia na 1 krowę \\
$\begin{array}{l}\text { Podwyższyć zyskowność inwestycji } \\
\text { (profitability of investments) }\end{array}$ & ROI \\
\hline
\end{tabular}

Źródło: Opracowanie własne na podstawie: Ch. Noell, M. Lund (2003).

Dosyć interesująca propozycja budowy BSC dla gospodarstw rolniczych, z uwzględnieniem perspektywy ,zrównoważonego rozwoju”, została wysunięta przez J. Jaworskiego i T. Kondraszuka (2013). Na szczególną uwagę zwraca wyodrębnienie aż 6 perspektyw: (1) finansowej, (2) potencjału, (3) procesów, (4) zrównoważonego rozwoju, (5) kupujacych, (6) gospodarstwa domowe$\mathrm{go}^{7}$. Niezwykle złożona wiązka celów i towarzyszących im mierników wymaga obecności rozbudowanego systemu informacyjnego, a zatem możliwości wdrożenia proponowanej przez J. Jaworskiego i T. Kondraszuka BSC są niewielkie, choć rolę wspomagającą, jak zauważają zresztą obaj badacze, mogą odegrać pracownicy ośrodków doradztwa rolniczego.

Biorąc pod uwaga wspólne obszary zarządzania strategicznego i rachunkowości zarządczej, szczególnie istotne może być rozpoznanie tzw. kluczowych czynników sukcesu (key success factor), które powinny być obiektem szczególnej uwagi wśród zarządzających. E. Nowak (2003, s. 289) za K. Wardem, zwraca

\footnotetext{
${ }^{7}$ Perspektywa gospodarstwa domowego wynika z założenia o swoistej „dualności” gospodarstwa wiejskiego, które, zdaniem T. Kondraszuka (2006), obejmuje gospodarstwo rolnicze i gospodarstwo domowe.
} 
uwagę na (a) „ukazywanie wyników ekonomicznych na tle osiągnięć menedżerskich”, (b) „dobór odpowiednich mierników dokonań”. Stopa zrównoważonego wzrostu może być zlokalizowana w konstrukcjach piramidalnych, służących do porządkowania dokonań w zależności od założonych celów strategicznych. Wymienić tu należy przede wszystkim: (1) piramidę pomiaru dokonań oraz (2) piramidę czynników kształtujących wartość, gdzie jednym z czynników determinujących wartość przedsiębiorstwa jest stopa wzrostu przychodów ze sprzedaży (por. Nowak E. 2003, s. 291). Stwarza to duże wyzwanie dla finansów rolnictwa, gdyż aparat dotyczący zarządzania wartością gospodarstwa rolniczego (wyłączając podmioty w formie spółek kapitałowych) nie został rozwinięty w takim stopniu, jak dla podmiotów reprezentujących pozostałe sektory gospodarki.

Z punktu widzenia polityki rolnej (zarówno na poziomie unijnym, jak i krajowym) znaczącym wyzwaniem będzie dyskusja nad problemem „tradeoff” między tradycyjnie pojmowanym zrównoważeniem a konkurencyjnością sektora rolnego (na poziomie krajów czy UE). Biorąc pod uwagę tendencje globalizacyjne, znajdujące wyraz $\mathrm{w}$ dążeniu do uzyskania korzyści z traktatów międzynarodowych TTIP i CETA, a także ramy polityki wyżywienia ludności na świecie, warto rozważyć kwestie związane z tzw. zrównoważoną intensyfikacją (sustainable intensification, SI), której zręby koncepcyjne powstały już w latach 90. XX w. (Franks J.R., 2014). Istotą SI - jako procesu - jest zwiększanie intensywności produkcji artykułów rolno-spożywczych (np. wzrost plonów) bez szkody dla środowiska naturalnego, wynikającej ze zmiany sposobu uprawy czy chowu (Firbank L.G. i in., 2013). Stopień zrównoważenia systemów produkcji rolniczej zależy od wielu wzajemnie powiązanych ze sobą czynników (w tym poziom intensyfikacji produkcji rolniczej, zarządzanie zasobami naturalnymi, typ produkcyjny, lokalizacja), które różnią się w ujęciu czasowym, a także w zależności od typu systemu produkcji rolniczej (Ripoll-Bosch R. i in., 2012).

Wyniki badań zespołu L.G. Firbank i in. (2012), obejmujące dobraną celowo próbę farm brytyjskich, wskazują, że rolnikom udało się realizować cele zakładane w zrównoważonej intensyfikacji. Farmerzy kierowali się głównie przesłanki finansowymi, m.in. związanymi z możliwością zmniejszenia kosztów produkcji, w tym także redukcji odpadów i zmniejszenia poziomu zanieczyszczeń. Istotną rolę odegrały transfery pieniężne w formie dopłat w ramach programów rolnośrodowiskowych - stanowiące rekompensatę za utrzymanie wysokiego poziomu bioróżnorodności. Z badań brytyjskich wynika, że niezbędne jest uproszczone podejście do oceny efektów zrównoważonej intensyfikacji w gospodarstwach rolniczych: za pomocą relatywnie niewielkiej liczby danych z tych podmiotów gospodarczych. Umożliwia to dokonanie pewnego rodzaju typologii wzorców zarządzania gospodarstwami rolniczymi, a jednocześnie stanowi narzędzie wspierające monitoring zrównoważenia.

Należy zauważyć, że operacjonalizacja kategorii wzrostu zrównoważonego stanowi i będzie stanowić duże wyzwanie dla ekonomistów i finansistów rol- 
nictwa. Na poziomie mikro istotne jest opracowanie koncepcji pomiaru, oceny i monitoringu zrównoważenia ( $\mathrm{z}$ uwzględnieniem ujęcia finansowego), czemu służyć mogą doświadczenia z wdrożenia ,prototypowych” kart BSC.Z perspektywy polityki agrarnej godne uwagi są rozwiązania metodyczne, dotyczące monitoringu i oceny możliwości dróg rozwoju sektora rolnego, również z uwzględnieniem zrównoważonej intensyfikacji.

\section{Wnioski i rekomendacje}

O ile relatywnie dobrze zostały rozpoznane na płaszczyźnie teoretycznej, aksjologicznej, metodologicznej i empirycznej kwestie dotyczące wymiaru ekonomicznego, społecznego i środowiskowego zrównoważenia gospodarstw rolniczych, to - w przypadku tych podmiotów - widoczna jest pewna luka dotycząca oceny zrównoważenia realizacji polityki finansowej przez gospodarstwo. System wsparcia finansowego w ramach WPR decyduje o większej subtelności i złożoności (m.in. wynika to z komplementarności i substytucyjności niektórych instrumentów, głównie w ramach II filara WPR) zjawisk finansowych w gospodarstw rolniczych. Ma to swoje konsekwencje, widoczne w pogłębieniu więzi gospodarstw rolniczych z infrastrukturą finansową.

Pojęcia „wzrostu zrównoważonego", „stopy wzrostu zrównoważonego”, „zrównoważonej intensyfikacji” mogą rozszerzyć dotychczasowe ramy analizy zrównoważenia gospodarstw rolniczych. Rozpatrując rozwój sektora rolnego (na poziomie krajowym, jak i unijnym), w tym szanse i zagrożenia wynikające z pewnego stopnia integracji gospodarczej z krajami Ameryki Północnej (z USA - w ramach TTIP, z Kanadą - w ramach CETA), coraz większego znaczenia nabiera konieczność poprawy konkurencyjności rolnictwa, z uwzględnieniem jednak barier o charakterze sozologicznym i społecznym. Istotną kwestią jest stopień posługiwania się przez decydentów politycznych kategorią racjonalności instrumentalnej (w ujęciu M. Webera), tzn. doboru odpowiednich środków do przyjętej w polityce rolnej wiązki celów. Na poziomie pojedynczego gospodarstwa ważne jest posługiwanie się prakseologicznymi kryteriami racjonalności mikroekonomicznej, biorąc pod uwagę ograniczoność zasobów naturalnych.

Przedstawiony paradygmat wzrostu zrównoważonego stanowi bazę teoretyczną dla konstruowania i udoskonalania instrumentarium wspomagającego zarządzanie gospodarstwem rolniczym. Dorobek z zakresu finansów przedsiębiorstw (w tym z uwzględnieniem podejścia „sustainability management”), a także próby dotyczące adaptacji BSC do potrzeb gospodarstw rolniczych są na tyle obiecujące, że można oczekiwać na upowszechnienie tych narzędzi przynajmniej wśród kierujących gospodarstwami o znacznej żywotności ekonomicznej.

Niedocenienie wymiaru finansowego zrównoważenia gospodarstw rolniczych należy traktować jako konsekwencję niedoceniania analizy przepływów pieniężnych. Opieranie się na kategorii dochodu rolniczego (w tym np. dochód $\mathrm{z}$ rodzinnego gospodarstwa rolniczego, net farm income), z pomijaniem sytuacji 
finansowej gospodarstwa, stanowi pewne uproszczenie spłycające ramy analityczne zrównoważenia. Ponadto, zdecydowana większość gospodarstw rolniczych w Polsce (wyłączając te, które uczestniczą w systemie FADN) nie dysponuje aparatem ewidencyjno-sprawozdawczym w ramach systemu rachunkowości. Prowadzi to do negatywnych konsekwencji, związanych m.in. z ograniczonymi możliwościami zintegrowanego planowania ekonomiczno-finansowo-środowiskowego w gospodarstwach rolniczych.

Przyszłe badania empiryczne dotyczące wymiaru finansowego zrównoważenia gospodarstw rolniczych powinny koncentrować się na kwestii rozpoznania efektów finansowych krótko- i długoterminowych ,tradycyjnie” pojmowanego zrównoważenia. Może stanowić to asumpt do zidentyfikowania motywów skłaniających rolników do intensyfikacji produkcji rolniczej. Niezbędna jest, wydaje się, rzetelna ocena wsparta wywiadem pogłębionym na reprezentatywnej próbie gospodarstw rolniczych lub rozważna analiza studiów przypadków. Wyniki tych badań mogą posłużyć klasyfikacji gospodarstw pod względem zdolności gospodarstw do absorbcji środków unijnych i krajowych, potencjalnie wspierających „zrównoważony rozwój rolnictwa”.

Pomiar zrównoważenia gospodarstw rolniczych powinien bardziej uwypuklać wymiar finansowy. Nie wynika to bynajmniej z nadmiernego eksponowania zjawisk finansowych w podmiotach sfery realnej, ale głębszego powiązania gospodarstw rolniczych z infrastrukturą finansową. Ujęcie modelowe zrównoważenia, czy nawet różnego rodzaju podejścia typologiczne lub mapy - użyteczne dla decydentów polityki rolnej - mogą zostać udoskonalone dzięki wyważonemu zwiększeniu liczby zmiennych gromadzonych przez system FADN.

\section{Literatura:}

1. Anderson M.: Economics, Steady State, http://umaine.edu/soe/files/2009/06/EconomicsSteady-State.pdf, 2012.

2. Baum R.: Sustainable development of agriculture and its assessment criteria. Journal of Agribusiness and Rural Development, z. 1(7), 2008, s. 5-15.

3. Bieker T.: Sustainability Management with the Balanced Scorecard, Corporate Sustainability. $5^{\text {th }}$ International Summer Academy on Technology Studies, Conference Proceedings (red. S. Karner, I. Oehme, U. Seebacher), Deutschlandsberg, Austria, July 13-19. 2003, http://sustyworks.in3online.com/downloads/Bieker_SA03.pdf (data dostępu: 10.03.2015).

4. Bodie Z., Merton R.C.: Finanse. Polskie Wydawnictwo Ekonomiczne, Warszawa 2003.

5. Budżetowe podstawy poprawy konkurencyjności polskiego rolnictwa (Synteza) (red. J. Kulawik). Program Wieloletni 2011-2014, nr 143. IERiGŻ-PIB, Warszawa 2014.

6. Carrizosa M.T.: Firm growth, persistence and multiplicity of equilibria: an analysis of Spanish manufacturing and service industries. University Rovira i Virgili July, 2006, http://www.tdx.cat/bitstream/handle/10803/8447/Chapter2.pdf? sequence=11 (data dostępu: 10.01.2015). 
7. Czyżewski A., Matuszczak A.: Dylematy kwestii agrarnej w panoramie dziejów. Zeszyty Naukowe SGGW w Warszawie - Ekonomika i Organizacja Gospodarki Żywnościowej 2011, $\mathrm{nr}$ 90, 5-23.

8. Escalante C.L., Turvey C.G,. Barry P.J., 2009: Farm business decisions and the sustainable growth challenge paradigm. Agricultural Finance Review, vol. 69, issue 2, 228-257.

9. Figge F., Hahn T., Schaltegger S., Wagner M.: The Sustainability Balanced Scorecard - linking sustainability management to business strategy. Business Strategy and the Environment, 11(2002), 2002, 269-284.

10. Finacial Times: Definition of business sustainability, http://lexicon.ft.com/Term?term =business-sustainability (data dostępu: 11.01.2015).

11. Firbank L.G., Elliott J., Drake B., Cao Y., Gooday R.: Evidence of sustainable intensification among British farms. Agriculture, Ecosystems and Environment 173 (2013), 2013, 58-65.

12. Flejterski S.: Zakończenie [w:] Komparatystyka finansów (aut. S. Flejterski, J.K. Solarz). Wydawnictwo C.H. Beck, Warszawa 2015.

13. Franks J.R.: Sustainable intensification: A UK perspective. Food Policy 47 (2014), 2014, 71-80.

14. Hadrich J.C., Olsen F.: Joint measurement of farm size and farm performance: A confirmatory factor analysis. Agriculture Finance Review, vol. 71, issue 3, 295-309.

15. Handschuh M., Dringenberg H., Jonk G., Maaß D., Niewiem S., Rasker T., Velthuis C.: A.T. Kearney: Optimales Wachstum: [w:] Exzellente Manangementscheidungen: Methoden, Handlungsempfehlungen. Best Practices (red.P.F.-J.Niermann, A.M. Schmutte). Springer Fachmedien, Wiesbaden 2014, 301-311.

16. Higgins R.C.: How much growth can a firm afford? Financial Management, 6(3), 1977, 7-16.

17. Jaworski J., Kondraszuk T.: Ramy koncepcyjne zastosowania strategicznej karty wyników w gospodarstwie wiejskim. Zeszyty Teoretyczne Rachunkowości, t. 74 (130), SKwP, Warszawa 2013, 45-63.

18. Kaplan R.S., Norton D.P.: Using the Balanced Scorecard as a strategic management system. Harvard Business Review, January-February, 1996, 75-85.

19. Kaplan R.S., Norton D.P.: The Balanced Scorecard as a strategic management system. Harvard Business Review, January-February, 1992, 71-79.

20. Kates R.W., Clark W.C., Corell R., Hall J.M., Jaeger C.C., Lowe I., McCarthy J.J., Schellnhuber H.J., Bolin B., Dickson N.M., Faucheux S., Gallopin G.C., Gruebler A., Huntley B., Jäger J., Jodha N.S., Kasperson R.E., Mabogunje A., Matson P., Mooney H., Moore III B., O'Riordan Th., Svedin U.: Sustainability Science. Research and Assessment Systems for Sustainability Program Discussion Paper 200033. Cambridge, MA: Environment and Natural Resources Program, Belfer Center for Science and International Affairs, Kennedy School of Government, Harvard University, 2000.

21. Kondraszuk T.: Gospodarstwo wiejskie jako podstawa rachunku ekonomicznego ujęcie metodyczne. Roczniki Naukowe Stowarzyszenia Ekonomistów Rolnictwa i Agrobiznesu, t. 8, z. 1, 2006, 80-84.

22. Kowalski A.: Evolution of the role and significance of agriculture for the Polish economy in 1989-2014. Problems of Agricultural Economics, Suplement do Zagadnień Ekonomiki Rolnej nr 4, 2014, 3-26. 
23. Lissitsa A.: A new strategic management instrument for agricultural enterprises in transition - The case study of balanced scorecard implementation in Ukraine. http://www. uni-goettingen.de/de/kat/download/1a64085fda29da93c0282f0f4f3518fc.pdf/posterbeitrag_lissitsa.pdf (data dostępu: 10.03.2015).

24. Majewski E., Ziętara W.: System celów w rolniczych gospodarstwach rodzinnych. Zagadnienia Ekonomiki Rolnej, nr 6, 1997, 29-43.

25. Mishra A.K., Harris J.M., Erickson K.W., Hallahan Ch., Detre J.D.: Drivers of agricultural profitability in the USA. Agricultural Finance Review, vol. 72, issue 3, 2012, 325-340.

26. Moss Ch.: Agricultural Finance. Routledge, Oxon 2013.

27. Noell C., Lund M.: The Balanced Scorecard (BSC) for Danish farms - vague framework or functional instrument? In: Farm management. Proceedings of the Nordic Association of Agricultural Scientists Seminar no. 345, 2003, 187-204.

28. Nörreklit H.: The balance on the balanced scorecard - a critical analysis of some of its assumptions. Management Accounting Research, 11(1), 2000, 65-88.

29. NowakE.:Zaawansowana rachunkowość zarządcza.Polskie Wydawnictwo Ekonomiczne, Warszawa 2003.

30. Olson K., Vu L.: Economic efficiency in farm households: trends, explanatory factors and estimation methods. Agricultural Economics, vol. 40, 2009, 587-599.

31. Paustian M., Theuvsen L.: Die Balanced Scorecard als Steuerungsinstrument in der Landwirtschaft. http.://oega.boku.ac.at/fileadmin/user_upload/Tagung/2014/Short_Papers_2014/IV-4-71_Paustian_et_al-OEGA_2014.pdf (data dostępu: 10.03.2015).

32. Perelman M.: Natural resources and agriculture under Capitalism: Marx's Economic Model. American Journal of Agricultural Economics, vol. 57, no. 4 (Nov. 1975), 1975, 701-704.

33. Ripoll-Bosch R., Díez-Unquera B., Ruiz R., Villalba D., Molina E., Joy M., Olaizola A., Bernués A.: An integrated sustainability assessment of mediterranean sheep farms with different degrees of intensification. Agricultural Systems 105 (2012), 2012, 46-56.

34. Saito K.: The emergence of Marx's Critique of modern agriculture. Ecological Insights from His Excerpt Notebooks, 2014, vol. 66, issue 05 (October), 25-46.

35. Scerri A., James P.: Accounting for sustainability: combining qualitative and quantitative research in developing "indicators" of sustainability. International Journal of Social Research Methodology, 13:1, 2010, 41-53.

36. Schimke A., Brenner Th.: Long-run factors growth - a study of German firms. Karlsruhe Institute of Technology (KIT), Department of Economics and Business Engineering. Working Paper Series in Economics, no. 21, April 2011.

37. Solarz J.K.: Nanofinanse. Codzienność zmienia świat. Wydawnictwo C.H. Beck, Warszawa 2012.

38. Wojtyna A.: Czy w wyniku kryzysu finansowego ekonomia otworzy się bardziej na psychologię? [w:] Węzeł polski. Bariery rozwoju z perspektywy ekonomicznej i psychologicznej (red. P. Kozłowski). Instytut Nauk Ekonomicznych PAN, Instytut Psychologii PAN, Warszawa 2011, s. 169-184.

39. Wrzaszcz W.: Czynniki kształtujące zrównoważenie gospodarstw rolnych. Journal of Agribusiness and Rural Development, 2012, z. 2(24), 285-296.

40. Wrzaszcz W.: Zrównoważenie indywidualnych gospodarstw rolnych w Polsce objętych FADN. Zagadnienia Ekonomiki Rolnej, nr 1, 2013, 73-90. 
41. Zegar J.S.: Współczesne wyzwania rolnictwa. WN PWN, Warszawa 2012.

42. Zhou H., Wit G. de: Determinants and dimensions of firm growth. EIM Research Reports, H200903, 2009.

43. Ziętara W.: System celów w państwowych przedsiębiorstwach rolniczych. Zagadnienia Ekonomiki Rolnej, nr 1, 1987.

44. Zrównoważenie polskiego rolnictwa (red. J.S. Zegar). Powszechny Spis Rolny 2010, GUS, Warszawa 2013.

MICHAE SOLIWODA

Institute of Agricultural and Food Economics

- National Research Institute

Warsaw

\title{
DILEMMAS IN A FINANCIAL DIMENSION OF SUSTAINABILITY OF FARMS
}

\begin{abstract}
Summary
Sustainability, as a specific inter- or even transdisciplinary 'metacategory', refers also to monetary processes. So far, a financial approach of sustainability of farms has not been explored.

The aim of this paper was to highlight some theoretical and methodological issues related to a financial dimension of sustainability of farms. The research objectives were as follows: (1) to link achievements in the area theoretical and methodological apparatus for sustainable growth (in financial terms) of farms to concepts of sustainability, (2) to identify associations between the growth of sustainable and selected agricultural farm management problems and agrarian policy. Relying on agricultural income category (including net farm income), excluding the farm's financial situation, leads to a significant simplification that may deform an analytical framework for sustainability. The terms "sustainable growth", "sustainable growth rate", "sustainable intensification" may extend the current framework for analysing the sustainability of farms, as well as be a prerequisite for constructing/ improving instruments that may support farm management, or monitoring and evaluation of the effects of agricultural policy.
\end{abstract}

Key words: sustainability, sustainable growth, agricultural finance, methodology of finance, farm

Zaakceptowano do druku - Accepted for print: 28.08.2015. 